DOI https://doi.org/10.18551/rjoas.2020-12.14

\title{
THE EFFECT OF SYSTEM QUALITY, INFORMATION QUALITY, AND PERCEIVED PLAYFULNESS ON THE USE OF TRANSPORTATION ONLINE APPLICATION
}

\author{
Marisse Kartika*, Dewi Ratnasari Heny \\ Department of Accounting, Faculty of Economics and Business, \\ University of Airlangga, Surabaya, Indonesia \\ *E-mail: marissekartika@gmail.com
}

\begin{abstract}
The study aimed to examine the effect of system quality, information quality and perceived playfulness on the use of online transportation applications. The most rapid development of information technology today is the use of smartphones. The inherent mobile apps and high frequency of use in today's society are online transport applications, such as Gojek, Grab, and Uber. The existence of several applications of online transport service providers make the user has several options and application providers trying to improve the quality of applications to attract users. This study collected questionnaire data with a total of 104 Indonesian respondents who using online transportation applications on their smart phones. The results of the analysis show that the perceived quality of the website (i.e. information and system quality) affects the perceived playfulness of the customer, and in turn, the satisfaction and intention to continue using it. The higher the quality level of the online transportation mobile application system, the more interested users will be to use it. Quality applications will increase the user's perceived playfulness, make users feel comfortable and have their own pleasure. Perceived playfulness will affect the intention to continue using the application.
\end{abstract}

\section{KEY WORDS}

System quality, information quality, perceived playfulness, intention to use.

Information technology will always have a tremendous impact on human life. The merger of computer technology with telecommunications has resulted in a revolution in the field of information systems. Information technology develops as a combination of computer and telecommunications technology with other technologies such as hardware, software, databases, networking, and other telecommunications equipment (William and Sawyer, 2003). The successful combination of computer technology with telecommunications is the internet. The Internet is a communication channel that is not limited by time or geography (Ahn et al. 2007). Computer technology with internet networks makes information can be easily disseminated. The most rapid development of information technology today is the use of smartphones.

Advances in mobile technology have allowed various applications to be developed that can be used by people who are on the move (Rachel et al. 2013). Almost everyone today has used a cell phone with this type of smart phone. Smartphones are now supported by various mobile applications that make it easier for users. So many people use mobile apps to contact friends, surf the internet, file content management, document creation and handling, entertainment and more. From anywhere, users can get mobile application facilities. People can do many things in daily life and business life. Mobile applications not only affect users, but also play an important role in business. Many business firms earn revenue using mobile applications. It can be said that mobile applications have an impact on society.

A survey conducted by the Indonesian Internet Network Providers Association (APJII) revealed that more than half of Indonesia's population is now connected to the internet. The survey conducted throughout 2016 found that 132.7 million Indonesians were connected to the internet. The total population of Indonesia alone is 256.2 million people. This indicates an increase of $51.8 \%$ compared to the number of internet users in 2014. A survey conducted by APJII in 2014, there were only 88 million internet users (tekno.kompas.com). The reason is the development of infrastructure and the ease of getting a smartphone. The survey data 
also reveals that the average internet accesser in Indonesia uses a handheld device. The statistics are as follows:

- 67.2 million people or 50.7 percent access via handheld devices and computers;

- 63.1 million people or 47.6 percent access from smartphones;

- 2.2 million people or 1.7 percent access only from computers.

The inherent mobile application and high frequency of use in today's society are online transportation applications, for example Gojek, Grab, and uber. This application offers convenience services and transportation services, motorbikes and cars. Even for Gojek, nowadays it has various services that develop not only transportation such as delivery of goods or packages or documents (Go-send), foods purchase and delivery services (Gofood), delivery of goods purchased by customers (Go-shop), transportation services in large quantities (Go-box), salon and make-up home services (Go-glam), home massage services (Go-massage), home cleaning services (Go-clean), and several other services. The Grab and Gojek applications now also provide services for goods or documents in addition to transportation, all of these services can be ordered through the mobile application downloaded on the user's smartphone.

The existence of several applications of online transport service providers make the user has several options and application providers trying to improve the quality of applications to attract users. Several previous studies have revealed that the quality of the website can directly affect consumer satisfaction and can lead to intent to buy or use (Bai et al. 2008; Chen and Cheng, 2009; Hsu et al., 2012). In an online-based business where consumer retention is a key success factor, much needed effective application development (Ahn et al., 2017). IS success model developed by DeLone and McLean (1992) initially has 6 main constructs namely system quality, information quality, use, user satisfication, individual impact and organizational impact. DeLone and McLean (2003) then developed the model by adding service quality factors. Three main categories namely the first system quality is the performance characteristics of mobile application system as a whole as easy to use by application users. Second is information quality is a measure of value perceived by the customer from the output generated by an application. While service quality is the availability of a communication mechanism to accept complaints from customers and there is a reward from service providers (Ahn et al., 2017). The three main categories of IS Success, first, system quality, is the performance characteristic of the overall mobile application system, such as being easy to use by application users. Second, information quality is a measure of the value perceived by customers from the output produced by an application. Meanwhile, service quality is the availability of a communication mechanism to receive complaints from customers and there is feedback from service providers (Ahn et al. 2017).

The IS success model in this study, namely the Gojek, Uber, and Grab applications, can only be seen from two sides, namely system quality and information quality because the application still does not have a place to accommodate comments, questions, and feedback from customers. So that the main variables used in this study are only these two qualities.

According to the research results of Ahn et al (2007), it is stated that playfulness plays an important role in developing attitudes towards the system and the intention to use the system. The intention to use the system (intention to use) can be defined as a form of the user's desire to use or reuse a certain object. In addition to seeing the effect on the intention of use in this study, it is also expanded by its effect on actual use. With system quality, information quality in online transportation applications affects the playfulness of application users which will affect the intention to use until finally using the application (actual use).

DeLone and McLean (2003) developed IS success model by adding aspects of human interaction i.e. service quality. Information quality, system quality and service quality of an application is expected to be a determinant of consumer satisfaction and intention to use. Nowadays, customers can choose their applications at will and replace vendors easily and at no cost. Online business today is not enough just to be satisfied with the number of downloaded apps or website visits but also have to work to convert regular customers into loyal customers. One way is to improve the quality of information systems and that meet the needs of its customers. According to Barnes and Vidgen (2001) states that the quality of a 
website or application can only be assessed and measured from the point of view of customers. The quality of the website or application affects the user's view of the application as it is the portal when the transaction will be performed (Ahn et al. 2007).

Information quality refers to the output quality of information systems (DeLone and McLean, 2003). Huh et al (1990) states there are four quality information that is accuracy, completeness, consistency, and currency. Accuracy states that the resulting information is accurate and error-free. Completeness refers that the required information has been met. Consistency refers to the absence of conflict between two datasets. Currency means information that is generated on time or uptodate. While the dimensions developed by DeLone and McLeon (2003) there are 5 dimensions of accuracy, currency, relevance, completeness, and understandability. Relevance refers to that information in accordance with the interests of the user. Undestandability refers to the user's ease of understanding the content in the application. High levels of information quality tend to provide information that can create comfort, and increase fun while using mobile applications (Koufaris, 2002).

The quality of the system represents the quality of the processing of the information system itself, which includes software and data components, this is a measure of the extent to which the system is technically reasonable (Gorla et al., 2010). According to DeLone and McLean (2003) users expect an easy to use application and easy to navigate. They also divide system quality into several criteria: usability, reliability, adaptability and responsive. Usability refers to the ease of use of the application system. Reliability refers to referring to a reliable application system that is used to indicate the ability of the software to remain in operation without having an error for a long time. Adaptability refers to a system that can adapt its content to changes in user requests. Responsive refers to how fast system can respond to user requests. A high level of system quality can give users more convenience, privacy, and faster response. The ability of the system can affect playfulness perceived by users when using mobile applications (Chung and Tan, 2004; Lederer et al, 2000).

DeLone and McLean suggest five variables to measure service quality: tangibility, reliability, responsiveness, assurance and empathy. Tangibiliy has the latest tools, software and support resources (eg call centers) aimed to responding to customers. Reliability refers to applications capable of performing and maintaining their support services. Responsiveness refers to the efficiency of service staff, and the expertise of service staff in responding to user complaints. Empathy shows that an app is designed with consumer thinking. High value apps in this variable tend to see frequent use and support consumers at every stage of purchase (Ahn et al.2004).

Many researchers have used TAM (Technology Acceptance Model) to predict the acceptance and use of information technology. TAM is based on Fishbein and Ajzen's Theory of Reasoned Action (TRA), which shows that social behavior is motivated by an individual's attitude to carry out the behavior, a function of one's beliefs about the outcome of the behavioral performance and the evaluation of the value of each result (Moon and Kim , 2001). The model in this study is based on the original TAM that has been extended by Moon and Kim. The following is the original model of TAM by Moon and Kim, 2001.

Based on the TAM, the external variables used in this study are web quality measurements developed by DeLone and McLeon (2003), system quality and information quality. Moon and Kim (2001) introduced perceived playfulness as a factor of intrinsic motivation that affects user acceptance of the World Wide Web (WWW). Users with perceived playfulness will feel that their attention will be focused on interaction with the mobile app (concentration), having a sense of engagement during interaction (curiosity), and finding a fun or exciting interaction (fun). They successfully combine playfulness with the TAM model and provide insight to the IS community in understanding how playfulness affects user attitudes and intentions. Their critical findings are theoretical support for the role of intrinsic factors that have a stronger effect than extrinsic effects (Hung et al., 2016).

Figure 1 is a research model used in this study. The quality of mobile transport online applications (GoJek, Uber, and Grab) can be seen from the two web quality measures of information quality and system quality that can affect the playfulness perceived by the users 
of the application, thereby impacting the user to continue using mobile transport online applications.

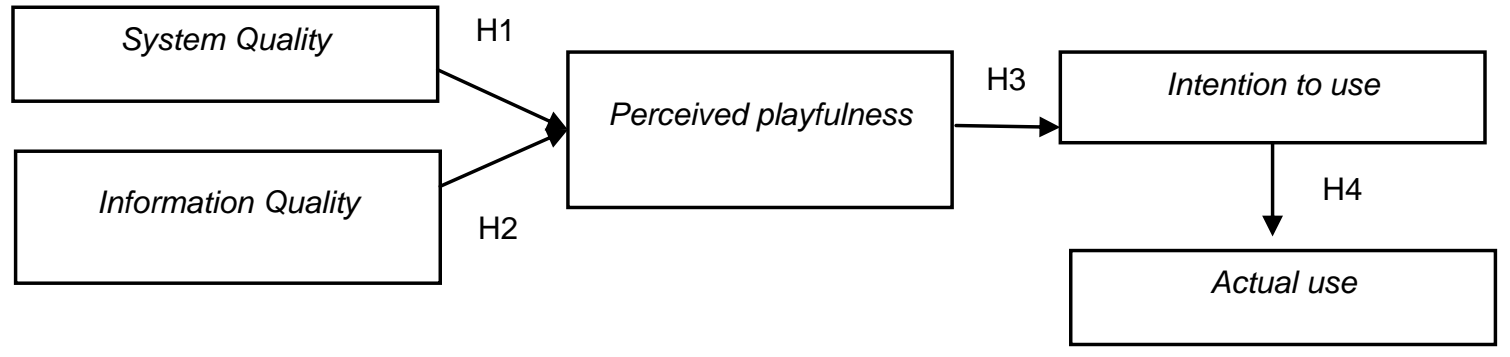

Figure 1 - Research model

The quality of the system can be seen from the ease of operating the application system, the speed of access that meets the expectations of users, the existence of a reliable application system to declare the ability of the software can still operate without experiencing disruption takes a long time, the flexibility and security of the application system so it can encourage intention users to continue using the app (DeLone and McLean, 2003).

High quality systems provide convenient, security and fast response to mobile applications so that system capabilities can affect user perceived playfulness felt by users (Lederer, Lheo, and Cheung, 2000). A quality system will cause perceived playfulness and curiosity during use (Mook and Kim, 2001). In the research of Ahn et al. (2007) found that website quality is categorized into system quality, has a significant effect on perceived playfulness. Based on this discussion, the first hypothesis is:

$\mathrm{H} 1$ : System quality has a positif effect on perceived playfulness.

Huh et al (1990) stated that there are four qualities of information that must be owned by websites or mobile applications, namely accuracy that allows error-free information, completeness of the information generated that meets user expectations, consistency and information produced at the right time. High levels of information quality tend to provide information that can lead to convenience, and increase pleasure when using mobile applications (Koufaris, 2002). The quality of information will lead to perceived playfulness, namely a feeling of curiosity during interactions and finding fun or interesting intrinsic interactions (Moon and Kim, 2001). Research Ahn et al (2007) found that the quality of websites categorized into information quality has a significant impact on perceived playfulness.

H2: Information quality has a positive influence on perceived playfulness.

Perceived playfulness affects the intention of someone to continue to visit an online site (Lin et al, 2005) because of a sense of curiosity, a focus on services provided, the feeling of fun and interest in mobile transport online applications. Ahn et al (2007) investigated the effect of playfulness on the acceptance of online retail users and investigated playfulness from a design quality perspective. From the IS success model, they identify three Web features: information, systems, and service quality that greatly affect the level of perceived engagement. They reinforce the findings from earlier work that playfulness is one of the prominent beliefs in building user attitudes and intentions to use in the context of the Internet (Hung et al., 2016).

H3: Perceived playfulness has a positive effect on intention to use using online transport applications.

DeLone and McLean (2003) include intention to use and actual use as a net benefit predictor. Although human behavior is sometimes difficult to measure, intention to use is a good measure of the likelihood that users will use the application (Wu andWang 2006). Both are predictive variables in the Technology Acceptance Model (Davis, 1989). Intention to use and actual use are therefore determined as different constructs in this study, and the relationships between them will be tested empirically. Thus, the following hypothesis is proposed: 
H4: Intention to use positively affects Actual use of users of online transport applications.

Data sample is from individual respondents who are users of mobile transport online application. Each respondent has at least downloaded the online transport app (GoJek, Uber, and Grab) in their smartphone and has used it. Data collected by using questionnaires distributed through online that is Google form.

Overall, out of 120 distributed, 104 questionnaires were acceptable and used for analysis. Fifty percent of respondents are male, and fifty-four percent are women. Detailed descriptive statistics relating to the characteristics of the respondents are shown in Table 1. Descriptive statistics were applied to provide respondent's profiles. Structural Equation Model (SEM) was used to test the hypothesized relationship between constructs in this study.

The measurement scale shown in the 'Appendix' 'was adapted from the existing literature and used to operationalize the research constructs in this study. The quality of information and system quality is measured using three and six indicators respectively, adjusted from Ahn et al. (2007). Perceived playfulness is perceived as measured by three items, adapted from Moon and Kim (2001). Intention to use is measured by three items, developed by Chen and Barnes (2007). Actual use is measured by a customized indicator of Chen and Cheng (2009). Each item is measured on a five-point Likert scale (ie $1=$ strongly disagree and 5 = strongly agree).

The questionnaire has been distributed a total of 120 , but from the data that has accumulated as many as 104 that can be accepted. Of the 104 respondents 54\% are female and $50 \%$ are male respondents. The largest respondents in this study aged between 18 to 25 years ie $32 \%$. And more than $60 \%$ are students. Details about the profile of the respondents can be seen in table 1 .

Table 1 - Profile of respondents $(n=104)$

\begin{tabular}{lll}
\hline Variable & Frequency & Percentage of total $(\%)$ \\
\hline Gender & 54 & \\
Female & 50 & $52 \%$ \\
Male & & $48 \%$ \\
Age & 30 & $29 \%$ \\
$<17$ th & 33 & $32 \%$ \\
$18-25$ th & 22 & $2 \%$ \\
$26-33$ th & 19 & $18 \%$ \\
$>$ 33 th & & \\
Job & 63 & $61 \%$ \\
Student & 33 & $32 \%$ \\
Employees & 8 & $8 \%$ \\
Entrepreneur & 0 & $0 \%$ \\
Others & & $5 \%$ \\
Incomes & 5 & $59 \%$ \\
< Rp 1.000.000 & 61 & $25 \%$ \\
Rp 1.000.000-2.500.000 & 26 & $2 \%$ \\
Rp 2.600.000-5.000.000 & 12 & $100 \%$ \\
$>$ Rp 5.000.000 & & \\
Total & 104 & \\
\hline
\end{tabular}

Using the Structural Equation Model, the hypothesized relationship in the proposed research model is tested and analyzed. The fit model results obtained R-squared $0.312, \mathrm{P}$ $<0.001$, adjusted R-squared 0.303, $\mathrm{P}<0.001$. VIF value obtained by 1.00 with accepted criteria when less than 5. Full collectivity VIF (AFVIF) of 3.222 with accepted criteria if less than 5. Then Sympson's paradox ratio $(S P R)=1,000$, with criteria accepted if $>=0.7$, Rsquared contribution ratio $(\mathrm{RSCR})=1,000$, with criteria accepted if $>=0.9$, Statistical suppression ratio $(S S R)=1,000$, with accepted criteria $>=0.7$ Nonlinear bivariate causality direction ratio $(\mathrm{NLBCDR})=1,000,=0.7$. From the results of the fit model can be indicated that it has a good fit model. 
The result of structural equation model can be seen from figure 2. The result shows that system quality and information quality that positively correlate with perceived playfulness. The result of the path diagram shows that $S Q$ and $I Q$ are positively and significantly correlated with perceived playfulness of a user of mobile transport online application. The probability value of both latent variables is less than 0.01 so it can be concluded that it has a significant relationship. System quality and Information quality are able to explain the perceived playfulness variance of $60 \%$. SQ and IQ are known to be positive against perceived playfulness seen from its positive beta value. This result supports previous research Ahn et al (2007) which shows the same result that system quality and Information quality affect the perceived playfulness of the mobile application users. These results support the hypotheses $\mathrm{H} 1$ and $\mathrm{H} 2$.

The latent variable perceived playfulness is able to explain the variance of the latent variable intention to use by $28 \%$. Viewed from figure 2 the results show that perceived playfulness is positively related and significant to intention to use with a probability value less than 0.01. These results support the H3 hypothesis and previous studies (Ahn et al. 2007, and Moon \& Kim 2000).

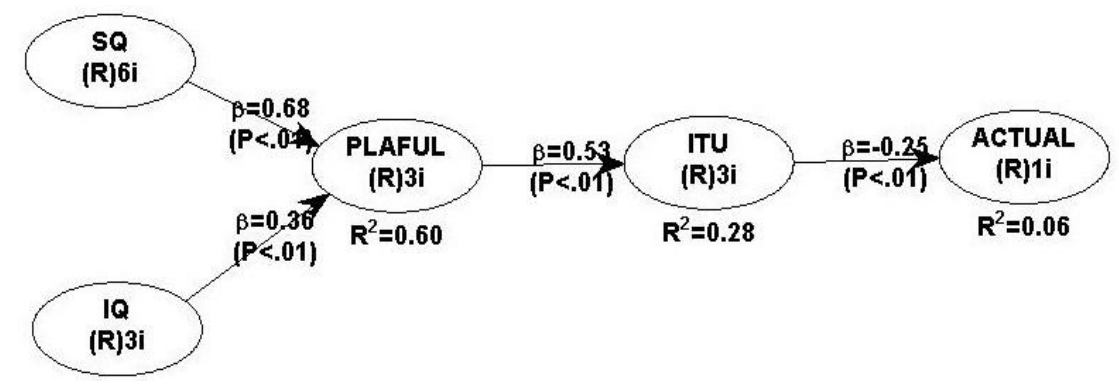

Figure 2 - Structural Equation Model

The latent variable intention to use describes the variant of the actual to use variable only by $6 \%$. The relationship of the ITU and ACTUAL variables is negative from beta -0.25 . These results indicate that intention to use because of the influence of playfulness does not necessarily make the user of mobile transport online applications use the application regularly and periodically. These results do not support previous research (Chung and Tan, 2003, Chen and Cheng, 2009) suggesting that users with playfulness will have strong behavioral to use a website and ultimately affect their actual use. The following figure 2 results from the structural equation model.

\section{CONCLUSION}

The results of this study provide support for the research framework presented in figure 1 and for hypotheses about the direction relationship between the model variables. The results of the analysis show that the perception of website quality (i.e. information and system quality) affects perceived playfulness perceived by customers, and in turn, their satisfaction and using intentions. The higher the quality level of the mobile transport application online system, the more interested users will be to use it. Quality applications will increase the user's perceived playfulness, make users feel comfortable and have their own pleasure. Perceived playfulness will affect the intention to continue using the application.

But in this study intention to use that resulted from the research model does not positively affect the actual to use of mobile transport application users online. This result makes sense because online mobile apps have other influences that make users use them on a regular basis. An example is the need of the application user. Owners of online transport apps on biased smartphones have a high degree of playfulness towards the mobile app and have intention to use but they do not require that application in frequent frequencies. For example, because the user already has a private vehicle. 


\section{APPENDIX}

Measurement item

System quality (SQ)

1. When using the Online Transport Application (GoJek, Uber, \& Grab), I feel the app has a fast response

2. When using the Online transport application (GoJek, Uber, \& Grab), I feel the application is not an error system

3. Online transport applications (GoJek, Uber, \& Grab) keep my personal data safe

4. Online transport applications (GoJek, Uber, \& Grab) are tailored to meet my various needs

5. Online transport apps (GoJek, Uber, \& Grab) I can use whenever I want to use them

6. Online transport applications (GoJek, Uber, \& Grab) are easy to use apps

Information quality (IQ)

7. I feel that the online transport application (GoJek, Uber, \& Grab) provides accurate information.

8. I feel that the online transport application (GoJek, Uber, \& Grab) provides the information I need

9. I feel that the online transport application (GoJek, Uber, \& Grab) provides up to date information / uptodate

Perceived Playfulness

10. When using the Online Transport Application (GoJek, Uber, \& Grab), I feel curious and have more curiosity about the app

11. When using the Online transport Application (GoJek, Uber, \& Grab), I feel more focused and concentrated on the app

12. When using the Online transport Application (GoJek, Uber, \& Grab), I feel pleasure

Intention to use (ITU)

13. I will continue to use the online transport Application (GoJek, Uber, \& Grab) in the future

14. I would recommend the online Transportation Application (GoJek, Uber, \& Grab) to my friends

15. I will regularly use the online transport Application (GoJek, Uber, \& Grab)

Actual to use (ATU)

16. Average monthly how many times do you use the online transport application (GoJek, Uber, \& Grab)

\section{REFERENCES}

1. Williams \& Sawyer. 2003. Using Information Technology: A Practical Introduction to Computers and Communications. London: Career Education.

2. Ahn ,T., Ryu, S., \& Han, I. 2007. The Impact of Web Quality and Playfulness on User Acceptance of Online Retailing. Information and Management 44(3):263-275.

3. Harrison, R., Flood, D. \& Duce, D. 2013. Usability of Mobile Applications: Literature Review and Rationale for a New Usability Model. Journal of Interaction Science 1:1.

4. Bai B, Law R., \& Wen I. 2008. The Impact of Website Quality on Customer Satisfaction and Purchase Intentions: Evidence from China Online Visitors. Int J Hosp Management 27(3):391-402.

5. Chien, Wen David Chen \& Chiang, Yu John Cheng.2009. Understanding consumer intention in online shopping: a respecification and validation of the DeLone and McLean model. Behaviour \& Information Technology, 28:4,335-345.

6. DeLone, W. \& McLean, E. 1992. Information Systems Success: The Quest for the Dependent Variable. Information Systems Research, 3(1), 69-95.

7. DeLone, W \& McLean, E. 2003. The DeLone and McLeon Model of Information Systems Success: A Ten Year Update. Journal of Management Information System, 19(4), 9-30.

8. Moon, J., \& Kim, Y. 2001. Extending the TAM for a World-Wide-Web Context. Information and Management 38(4):217-230.

9. Barnes,S., \& Vidgen, R. 2001. An Evaluation of Cyberbookshops: The WebQual Method. International Journal of Electronic Commerce 6(1), 11-30.

10. Koufaris, M. 2002. Applying The Technology Acceptence Model and Flow Theory to Online Consumer Behavior. Information systems research 13(2):205-223.

11. Gorla, N., Somers, T.M., \& Wong, B. 2010. Organizational Impact of System Quality, and Service Quality. The Journal of Strategic Information Systems 19(3):207-228.

12. Chung J., \& Tan, F.B. 2004. Antecedents of Perceived Playfulness: An Exploratory Study On User Acceptance of General Information-searching Websites. Information and Management 41(7):869-88.

13. Lederer, A.L., Maupin, D.J., \& Zhuang, Y. 2000. The Technology Acceptance Model and the World Wide Web. Decision Support Systems 29(3):269-282. 
14. Hung, S.Y., Tsai, J.C., \& Chou, S.T. 2016. Decomposing Perceived Playfulness: A Contextual Examination of Two Social Networking Sites. Information and Management 53(2016) 698-716.

15. Davis, F. D., 1989. Perceived Playfulness, Perceived Ease of Use, and User Acceptance of Information Technology. MIS Quarterly 13(3) 319-340.

16. Tan, M. \& Teo, T. 2000. Factors Influencing the Adoption of Internet Banking Journal of the AIS 1(5), 1-44.

17. Sugiono. 2012. Metode Penelitian Kuantitatif. Kualitatif, dan R \& D. Bandung: Alfabeta.

18. Schreiber, J.B., Nora, A., Stage, F.K. et al. 2006. Reporting Structural Equation Modeling and Confirmatory Factor Analysis Results: A Review. The Journal of Educational Research. Vol 99(No. 6).

19. Chinoma, R. 2013. The Influence of Perceived Ease to Use and Perceived Usefulness on Trust and Intention to Use Mobile Social Software. African Journal for Physical, Health Education, Recreation and Dance, Vol. 19 No 2 258-273.

20. Ferdinand, A. 2002. Structural Equation Modeling Dalam Penelitian Manajemen. Semarang: BP UNDIP. 